\title{
Digital levendegørelse
}

\section{- 1700-tals faktionsleg på Facebook}

Mette Boritz*, Mia Ramsing Jensen*,

Charlotte S.H. Jensen* OG IDA Lund-Andersen*

Title: Digital living history - playing with eighteenth-century "faction" on Facebook.

Abstract: Living history is becoming increasingly popular within the museum world, and is found in many different forms. In this article, we wish to introduce the term "digital living history" and consider what happens when a decision is made to generate living history in digital form in conjunction with cultural history and museum collections, and what kinds of potential and which challenges are involved in such a process. At the same time, the article will consider to what extent "digital living history" can be used to engage in a dialogue with target groups not often encountered in museum contexts. The article is based on a project about a fictive young girl named Ida Charlotte, who posted an account of her thoughts and experiences on Facebook, as these unfolded day by day over a sixmonth period in 1772. This project, which was targeted at young women and girls, was run by the National Museum of Denmark in 2010, and was followed by a series of surveys that are examined in this article.

Key words: Digital living history,"faction" games, eighteenth century, user involvement, Facebook.

\section{IDA Charlotte pÅ FACEBOOK}

Den 1. april 2010 gik Nationalmuseet på Facebook med den fiktive 19-årige borgerskabspige Ida Charlotte Finnelstrup. Den unge Ida Charlotte var netop rejst fra Ålborg til København, hvor hun skulle opholde sig et halvt år hos sin onkel og tante. Herefter var målet, at hun skulle rejse til De Vestindiske Øer, hvor hendes forlovede Jørgen - og et liv som frue - ventede. I det halve år, hun var i København, skrev Ida Charlotte på sin Facebookside, og det var gennem disse daglige skrivelser, at 1700-tallet langsomt blev vakt til live. Det var her, at hun berettede om både store og små hændelser og om livet i almindelighed, som det formede sig i Kongens København i året 1772. Det var også her, hun delte både sorger og glæder med sine Facebook-venner og kunne spørge dem til råds, når tvivlen nagede hende. 
Med støtte fra Kulturarvsstyrelsen satte $\mathrm{Na}$ tionalmuseet sig for at afprøve, om det er muligt at anvende netop Facebook som redskab til at levendegøre kulturhistorien. Overordnet handler levendegørelse om at simulere liv i en anden tid (Anderson 1991). Det er en metode, som kan anvendes til at præsentere en historisk periode ved hjælp af aktører, som i handling portrætterer og udlever forholdene i en given tid og på et givent sted (Hunt 2004). I disse år bliver der netop eksperimenteret med mange former for levendegørelse, og brugen udvikler sig hele tiden (Drost Aakjær 2008). I denne artikel vil en ny form føje sig til, nemlig den Digitale levendegørelse. Den vil med udgangspunkt i projektet om den fiktive borgerskabspige Ida Charlotte og hendes skriblerier på Facebook søge at analysere, hvad der sker og hvilke potentialer og udfordringer, det rummer for museerne, når de søger at levendegøre kulturhistorien og museernes samlinger digitalt. Samtidig vil den forholde sig til, hvorvidt digital levendegørelse kan bruges til at komme i dialog med en målgruppe, som ikke, eller kun i ringe grad, bruger museerne i dette tilfælde unge kvinder i alderen 15-30 år. Ifølge den Nationale Brugerundersøgelse udgør de 14-29 årige kun 13 \% af museernes samlede besøgstal, og ser man på hvor mange, der kommer uden for skoletiden er det sikkert endnu mindre (KUAS 2009). I stedet for $\mathrm{i}$ første omgang at få de unge kvinder til at gå på museum, var intentionen at bringe museets samlinger og viden i spil der, hvor de unge kvinder selv befinder sig. Det var derfor oplagt at anvende Facebook som platform, idet brugen af Facebook er særdeles udbredt blandt unge kvinder i Danmark. Beregner man løseligt ud fra Facebooks egne annonceoplysninger, tæller gruppen af kvindelige brugere til og med de 35 år over $750.000 .^{1}$

\section{LEVENDEGØRELSE OG RE-ENTACTMENT}

Det at undersøge levendegørelsen af historien vinder stadig større tilslutning inden for museumsverdenen, og særligt på Frilandsmuseer er det en formidlingsform som har vundet indpas. Levendegørelse er en iscenesat konstruktion, som i praksis kan antage mange former og praktiseres i form af rollespil, teater, demonstration af håndværk, brug af avancerede AV-midler, ved inddragelse af publikum osv. (Jørgensen 2003). At gøre historien levende kan med andre ord gøres på et utal af måder, og overordnet omfatter begrebet levendegørelse flere forskellige tilgange. Der tales fx. både om levendegørelse og om re-entactment, som repræsenterer forskellige tilgange til det at levendegøre historien. Levendegørelse er en meget bred term, som anvendes til at beskrive historisk autentiske aktiviteter udført $\mathrm{i}$ en konkret kontekst, fx. på et Frilandsmuseum. Aktørerne, som deltager i levendegørelsen, kan, for nogens vedkommende, være i rolle, mens andre "blot" er klædt ud. Re-enactment betegner $\mathrm{i}$ reglen genskabelsen af en enkelt historisk episode eller hændelse (fx. et historisk slag), hvor mange aktører ofte er involveret, og hvor handlingen, kostumerne og selve slaget er vigtigere end det talte ord. ${ }^{2}$ Hvor reentactment nærmer sig en forestilling, der har udøvere og tilskuere, så ligger levendegørelse i sin form nærmere "aktivitet" end "forestilling”. Med levendegørelse kan gæster, brugere etc. vælge at være tilskuere, men de kan også interagere aktivt med de aktører, som skaber en historisk illusion. Og hvor re-entactment primært handler om at rekonstruere historiske begivenheder, som f.eks. historiske slag, så korrekt som muligt, så fokuserer man med levendegørelse i højere grad på hverdagslivet, som det formede sig på et givent sted $\mathrm{i}$ en gi- 
62 ven tid. Begge metoder til at søge at levendegøre historien i den analoge verden har også vundet indpas $\mathrm{i}$ den digitale verden. Der er bl.a. flere eksempler på re-enactment-genren, hvor én eller flere personer genskaber et historisk hændelsesforløb så præcist og historisk korrekt som muligt. Kendte eksempler er "Harry's blog", som offentliggjorde soldaten Harry Lamins breve fra første verdenskrigs skyttegrave i simuleret realtid. De blev blogget præcis 90 år efter, at de var skrevet - et projekt der fik masser af læsere og opmærksomhed fra medierne.

Mikrobloggingtjenesten Twitter er også flere gange blevet brugt til at genskabe - twitenacte $-\mathrm{fx}$ historiske begivenheder som Slaget ved Gettysburg og JFK's valgkamp. Storbritanniens rigsarkiv bringer med ukwarcabinet historien om anden verdenskrig - baseret på originale kilder, og Masschusetts Historical Society twitter John Quincy Adams' liv. Et andet eksempel kan også være initiativer, som bruger originale personlige kilder - fx @genny_spencer, der twitter en ung piges dagbogsnotater fra 1930'erne eller@samuelpepys, der tager udgangspunkt i den flittige engelske dagbogsskriver Samuel Pepy's mange bind. Det kan diskuteres, om "digital re-enactment" er et rimeligt begreb at anvende i sammenhænge, hvor der kun er én udøvende "re-enacter", der fx blogger og twitter, men i situationer, hvor flere personer interagerer, er ligheden med fysisk re-enactment slående. Her er det nødvendigt at kende det virkelige hændelsesforløb og de agerendes indbyrdes forhold, timing etc., præcis som hvis et slag eller lignende genopføres.

Projektet om Ida Charlotte er mere et udtryk for digital levendegørelse, end digital reenactment. Levendegørelse baserer sig ofte på andre kreative og symbolske former - specielt drama, ritualer eller leg. Det er ofte teateragtigt med brug af kostumer, og kan også opfattes som en slags rollespil, hvor man har mulighed for at identificere sig med historiske karakterer. Det var netop denne aktive ageren og denne identifikation, som projektet om Ida Charlotte gerne måtte ramme. En forskel mellem digital og analog levendegørelse, som også skulle afprøves, er den simulerede realtid, som i den digitale form kan opretholdes over et meget længere tidsrum, end det er muligt analogt. I projektet Ida Charlotte var levendegørelsen således planlagt til at løbe over $1 / 2$ år, hvilket næppe havde været praktisk muligt i den analoge verden.

Brugen af levendegørelse i museumsverdenen er langt fra et nyt fænomen, men at det i dag har fået så stor en udbredelse skyldes, ifølge den amerikanske historieprofessor Jay Anderson, at mange i dag virkelig interesserer sig for, hvordan hverdagslivet er blevet levet i tidligere tider (Anderson 1986). Denne interesse for hverdagslivet $\mathrm{i}$ fortiden opstod allerede $\mathrm{i}$ Europa i sidste halvdel af 1800-tallet, hvor man fra museernes side begyndte at indsamle genstande, som bl.a. tog udgangspunkt i bøndernes hverdagsliv, der i takt med industrialiseringen ændrede sig markant. Det gjaldt dermed om at indsamle denne kulturarv inden den forsvandt, men også om at bruge den aktivt og fremadrettet til bl.a. national- og identitetsskabende formål (Stoklund, Floris \& Vasström). Men det handlede også om at få folket til at identificere sig med historien. I 1878 udstillede den svenske museumsmand Arthur Hazelius på Verdensudstillingen i Paris et bondestueinteriør, hvor dukker klædt i originale dragter stod sørgende omkring "Lillans sidsta bädd". Konceptet med at dramatisere hverdagsliv $i$ et museumsinteriør overførte Hazelius til museumsverdenen med ønsket 
om, at et museumsbesøg godt måtte være med til at vække følelser hos publikum.

I Nordamerika blev levendegørelse med levende og udklædte aktører, der agerede eller dramatiserede over historie, populært allerede i midten af det 20. århundrede. Der skulle imidlertid gå noget længere tid, inden levendegørelse for alvor kom til at indgå som en formidlingsstrategi på de europæiske museer, hvor det at levendegøre længe begrænsede sig til demonstration af håndværk eller folkedans, når bølgerne gik højt. Men i de seneste årtier er levendegørelse blevet en strategi eller metode, som bruges i stadig stigende grad. Gennem levendegørelse søger museerne at hjælpe de besøgende til at forstå kulturen i en bestemt periode, eller hvordan livet blev levet på et bestemt sted (Reinheim 1991:170). Ifølge Anderson kan der være flere grunde til at anvende levendegørelse som formidlingsgreb (Anderson 1991). For det første kan det være et greb til at simulere livet i en anden tidsalder og få folk til at leve sig ind i denne samt hverdagslivets gøremål dengang. Levendegørelse kan også være en metode til at fortolke museernes genstande på nye måder og sætte genstande i spil, som ellers står passive hen. I den henseende kan levendegørelse fungere som et forskningsværktøj for det, Anderson kalder eksperimentel arkæologi. Endelig kan levendegørelse tjene som en underholdende fritidsaktivitet for folk, som elsker historie og er interesseret $\mathrm{i}$ at finde ud af mere om, hvordan livet $\mathrm{i}$ fortiden virkelig var. Med levendegørelse er det imidlertid ikke en fortid der vises, men en fortid der skabes. Og det er lige præcis dét, levendegørelse kritiseres for.

"Kan man stoppe tiden - fryse et øjeblik vække historien til live? Kan man få os, som lever i dag, til at forstå hvordan, det var at leve dengang?" Sådan spurgte museumsformidler
Ingrid Zakrisson i MID's nyhedsbrev i 2003. At søge at levendegøre fortiden er langt fra uproblematisk, og spørgsmålet er om, eller i hvilket omfang, det overhovedet lader sig gøre. Svaret på Zakrissons spørgsmål må derfor være dobbelttydigt. For vi vil aldrig præcis kunne gengive fortiden og de tanker som fortidens mennesker gjorde sig. Ifølge etnologen Hans Ole Hansen er det ikke muligt at levendegøre noget fortidigt - det være sig 1000 år gammelt eller 10 dage gammelt, for som han fremhæver, vil vi aldrig kende hele sandheden, og derfor kan vi kun levendegøre dele af fortiden eller en valgt forestilling om fortiden (Hansen 2003). Der er nemlig så meget ved fortiden, vi simpelthen ikke ved, bl.a. om sprog og kultur i tidligere epoker, og det rejser selvfølgelig spørgsmålet om, hvorvidt levendegørelse i virkeligheden i højere grad er med til at mislede folks opfattelse af fortiden, fordi der er så meget, som ikke kan fortælles og som ikke bliver fortalt (Hunt 2004: 389). Levendegørelse som medierende formidlingsform kan derfor let lede til enten en stereotypisering eller en idealisering af fortiden (Carstensen et. al 2008). Omvendt kan levendegørelsen, hvad enten den er $100 \%$ korrekt eller ej, bidrage til at gøre historien vedkommende og vække interesse, hvilket i høj grad var intentionen med projektet om Ida Charlotte.

\section{FAKTIONSLEG}

Hvordan får man unge kvinder, der måske ikke engang er historieinteresserede, til at engagere sig i 1700-tallets kulturhistorie? Hvordan giver man dem bedst et indblik i en tid, der med sine store kjoler, pudderparykker, manglende underbukser, fornuftsægteskaber og utallige visitter synes meget anderledes end i dag, men hvor det alligevel ikke er alt, der er 
64 så anderledes endda? Det umiddelbare bud blev at skabe en person, som det var muligt for de unge at identificere sig med eller spejle sig selv $\mathrm{i}$ - en person, der kunne bruges som omdrejningspunkt for at diskutere en lang række fænomener, som er interessante på tværs af tid, som fx kærlighed, moral, ægteskab, fødsel, $\mathrm{d} ø \mathrm{~d}$, tøj, hår og makeup. Ida Charlotte blev skabt som faktion. Faktion er et begreb, som er kendt fra bl.a. tv og betegner et produkt, som bygger på både fakta og fiktion. Virkelighed og historisk realitet blandes her med opdigtede figurer, hændelsesforløb og steder. Både fakta og fiktion kan noget, men også noget forskelligt, når det handler om at engagere folk i forhold til kulturhistorien. En fiktiv person kan frit tillægges følelser, tanker, værdier og handlinger. Men hvis man vil holde sig på faglighedens dydige sti, kan tilsvarende være svært at tillægge en person, som virkeligt har levet uden hurtigt at havne $\mathrm{i}$ historieforvanskning. Kildebelægget og forskningen omkring borgerskabskvinder $\mathrm{i}$ slutningen af 1700 -tallet er fragmentarisk, og det vil være svært at komme helt tæt på en af tidens kvinder uden at skulle digte en del (Boritz 2000). Med den fiktive Ida Charlotte kunne der digtes og dramatiseres mere frit - en digtning som dog foregik på så plausibelt et grundlag som muligt. Fx fik Ida Charlotte et nøje konstrueret stamtræ, og der blev skabt et persongalleri, hvor alle fik navne, som passede til tiden og standen. Samtidig var det afgørende, at projektet også skulle bygge på den videnskabelige viden, vi i dag har om 1700-tallet. Brugerne skulle ikke kun underholdes men også lære. Med Ida Charlotte blev der således skabt en faktionsleg, hvor den fiktive personlige fortælling blev krydret med fakta fra tiden som f.eks. henrettelsen af Kong Christian VII's livlæge Struensee, opskrifter fra 1700-tals kogebøger, gode råd fra husmoderbøger og billeder af genstande fra Nationalmuseets samlinger. Dagbøger m.m. bidrog til, at Ida Charlottes dage formede sig efter, hvad der reelt skete i 1772. Da hun den 1. maj tog til maskebal med sin onkel, var det fordi, der i 1772 faktisk blev afholdt et maskebal i København på den dato, og på samme vis så hun de stykker, som reelt blev vist på teatre i København. Andre typer af fakta fulgte ikke den konkrete dato, men blev alligevel brugt som forlæg. Det gælder antallet af visitter, regler for sorg og begravelsesskik, synet på og behandlingen af sygdomme, overtro, holdningen til forbrydere, behandlingen af tjenestefolk, praktiske daglige gøremål og endda mængden af pudder som skulle indkøbes. ${ }^{3}$

Ida Charlottes historie på Facebook er med andre ord ikke egentlig historieskrivning, og lader sig samtidig heller ikke passe ind i de mere traditionelle litterære genrer. Det er frem for alt ikke som en roman eller en novelle, der skrives af en forfatter fra ende til anden. Hovedformålet var da heller ikke at fortalle en historie, men i stedet at skabe eller opleve en historie, sammen med en gruppe af interesserede. I et sådant setup bliver historien til, mens den foregår - dvs. i realtid. Fra Nationalmuseets side var der naturligvis lagt visse rammer og bestemt en række nedslagspunkter. Der var udvalgt nogle væsentlige pointer, som gerne skulle være en del af oplevelsen, og udformet en skitse til et storyboard. Men oven på dette skelet af historiske realia skabte brugere og arrangører i fællesskab det "kød på historien", som gav figuren og fortællingen liv. Realtid er formidlingens svar på slow-food. I en film rulles begivenheder frem $i$ hastigt tempo, og et helt liv kan fortælles på 90 minutter. I en bog kan læseren smugkigge på handlingen ved at bladre nogle sider frem - eller endda 
springe helt hen til slutningen og finde ud af, hvem morderen er, uden at have fulgt hele historien. Men i realtid foregår alt, også rejser, brevvekslinger m.m., ideelt set i samme tempo som det ville være blevet levet i 1772 . I en sådan proces er der ingen genveje eller smuthuller til at finde ud af, hvad der sker. Vi har derfor valgt at give Ida Charlottes historie på Facebook betegnelsen "faktionsleg". Ved at forbinde faktionsbegrebet med "leg" indikeres en uformel aktivitet men samtidig også et fokus på aktivitet. En invitation til leg er en opfordring til et samvær, der bygger på gensidighed og udfordrer til kreativitet. Hele intentionen med projektet var at de, der fulgte Ida Charlottes liv og færden, ikke skulle være passive beskuere men have mulighed for også aktivt at deltage. Ønsket var at de, som brugere, skulle være med til at skabe historien - med deres spørgsmål, kommentarer, interesser og valg. Projektet har med andre ord haft aktiv brugerinddragelse og deltagelse som målsætning.

\section{Det DELTAGende MUSEUM}

Museerne står i dag over for store udfordringer. Antallet af besøgende falder på mange museer, og rundt om $i$ verden ses et behov for, at museerne genopfinder sig selv og deres samfundsmæssige rolle, hvis de ikke skal stå tilbage som støvede templer, der ikke er i brug. Rundt om på museerne bliver der derfor tænkt mange tanker om, hvilken rolle og funktion de skal spille i samfundet (Gurian 2007). Fra politisk side er der samtidig et stigende krav om, at museerne ikke kun skal tilgodese dem, som vanligt kommer på museerne, men også søge at tiltrække nye brugergrupper. I dag arbejder mange museer derfor aktivt med at komme ud til et bredere publikum, samt med at søge at give den brede be- folkning et større ejerskab til samlingerne (Message 2006). Det stiller krav til museerne om også at skulle arbejde på nye måder. Nina Simon peger i sin bog: "The Participatory Museum" (Simon 2010) på, at hvis museer vil i kontakt med brugerne, og hvis museerne vil demonstrere deres relevans og værdi, så gælder det om aktivt at engagere folk og om at gøre dem til deltagere i stedet for blot at være passive beskuere. Hun fremhæver at folk i dag forventer at få en mulighed for at respondere og for at blive taget alvorligt. Nutidens museumsgængere vil have lov til at diskutere, dele og forholde sig til det de oplever. Derfor skal museerne i højere grad bestræbe sig på at fungere som "deltagende kulturelle institutioner", forstået som steder, hvor de besøgende kan skabe, dele og komme i dialog med hinanden omkring et indhold eller emne.

Ida Charlottes side på Facebook fungerede som et mini-community inden for det store community, Facebooks, rammer. På både Facebook og andre netværkssites findes mange mindre, brugerskabte communities, hvor kulturarv fungerer både som socialt objekt og som informelt læringsobjekt. At skabe nye netværk, selv for en kortere tid, er ikke nogen enkelt opgave. Et community skal skabe værdi for de deltagende, men brugeraktivitet kommer ikke, blot fordi en platform er skabt, stillet til rådighed og forsynet med et grundlæggende indhold. Samtidig er det vigtigt ikke at lade aktiviteten være for åben. I indlægget "Participation Inequality: Encouraging More Users to Contribute" lister usabilityeksperten Jakob Nielsen på useit.com en række faktorer, som han tilbage i 2006 fandt, kunne få betydning for interesse $i$ at deltage:

- Gør det lettere at deltage

- Gør deltagelse til en sidegevinst 
- Rediger, skab ikke fra bunden

- Beløn deltagelse - men overdriv ikke

- Forfrem kvalitets-bidragsydere

Ved at anvende Facebook som platform blev en række af disse faktorer tilgodeset. Det er fx nemt at deltage $i$ et digitalt rum, hvor teknologi m.m. allerede er kendt. Et andet væsentligt aspekt er, at det basale niveau for deltagelse, at "like" eller "synes godt om" er meget enkelt. Brugeren behøver ikke engang at deltage med selvformuleret tekst, men kan nøjes med et museklik. En vigtig præmis for brug af sociale medier er, at antallet af brugere, som vil bidrage med indhold, formentlig vil være langt mindre end antallet af deltagere. Hvis målet derfor er at opnå en høj deltagelsesprocent, er det værd at overveje en form for incitamentstruktur og - i hvert fald i den indledende fase - at arbejde aktivt for at drive aktiviteten fremad, i stedet for blot at skabe rammen, og derefter overlade det til brugerne selv at deltage og skabe relationer. Det er derfor vigtigt at have en manager, for at få et netværks-community til at fungere. Manageren har en vigtig rolle som både facilitator og deltager. Vigtigt er det frem for alt at lytte til de udsagn og aktiviteter, som foregår og undgå "sælgeragtig" adfærd, samt at skabe relationer, autenticitet og nærvær. Navnlig i begyndelsen af et communitys liv er dette i høj grad afhængigt af grundlæggerens aktivitet. Først i en senere fase kan fællesskabets medlemmer skabe tværgående relationer, og lidt efter lidt frigøre sig fra såvel grundlæggerens som de første eksperters eller med-facilitatorers autoritet. Simon peger på, at hvis man bruger det at deltage som et værktøj, så er det nødvendigt at definere nogle klare roller for brugerne om, hvad de må og hvad der forventes af dem (Simon 2010). Samtidig må institutionerne være gea- ret til, at når folk vælger at deltage og bidrage til en institution, forventer de også at deres indsats bliver integreret og taget alvorligt (Simon 2010). Institutionerne må lære at stole på brugernes evner til at være både medskabende, bidragende, distribuerende osv. Det fordrer samtidig en villighed til, fra museernes side, at indtage en ny rolle. Fra at være autoritære eksperter, der øser af deres viden, bliver den rolle museerne skal indtage i højere grad rollen som vidensfacilitator museet og brugerne imellem (Gurian 2007).

\section{HVORDAN SKABTES GRUNDLAG FOR DELTAGELSE?}

Intentionen med projektet var at brugerne, deres interesser, behov og ønsker skulle være med til at drive historien om Ida Charlotte frem. Spørgsmålet var blot hvilke ønsker, de havde. Hvad skal der til for at få unge kvinder til at engagere sig i 1700-tallet? For at komme dette lidt nærmere, blev der etableret en fokusgruppe bestående af 7 kvinder $\mathrm{i}$ alderen 14-30 år. Pigerne var ikke specielt interesserede i historie, for nogle af dem var det næsten tværtom. Det var heller ikke alle i fokusgruppen, som gik på museum - en enkelt havde $\mathrm{fx}$ aldrig været på Nationalmuseet før. Ideen med at invitere en fokusgruppe var desuden at søge at få gruppens medlemmer til at komme med nogle gode pejlemærker til, hvilke emner og historier, det kunne være interessant at inddrage i projektet, samt hvilke andre elementer som musik, film, quizzer, blogs eller hvilken type af fotos som kunne være gode at bruge. Det var imidlertid ikke alle de gode forslag fokusgruppen kom med, som det var muligt at imødekomme. Fokusgruppen anbefalede $\mathrm{fx}$ helt entydigt, at Ida Charlotte selvfølgelig skulle være oprettet som en person på Facebook, 
så det var muligt at blive ven med hende personligt. Dette viste sig imidlertid ikke muligt, da det ikke er tilladt at oprette profiler i andres navn på Facebook, hvilket Nationalmuseet valgte at tolke sådan, at det også gælder fiktive personer. Ida Charlotte fik derfor sin egen side i stedet for. Den helt personlige veninderelation med Ida Charlotte blev dermed ikke muligt, hvilket nogle af de yngste brugere beklagede undervejs, mens de lidt ældre ikke rigtigt havde bidt mærke i, om det var en "person" eller en "side".

Ved at bruge Facebook som formidlingsplatform, var der via mediets design lagt op til at brugerne skulle inddrages og interagere med den unge pige. Som udgangspunkt er Facebook et socialt medie skabt til netop kommunikation og for så vidt også til interaktion. Det er dog ikke en forudsætning, at man skal deltage. Facebooks design lægger op til, at brugerne kan interagere på flere forskellige måder. De kan kommentere på updates, billeder, links m.m. men også blot nøjes med at trykke "synes godt om" og dermed ikke indgå i direkte dialog.

Meget af den umiddelbare interaktion med brugerne foregik ved, at de kommenterede på Ida Charlottes daglige stausopdateringer. Det stod dog hurtigt klart, at opdateringer i sig selv ikke altid er nok, til at få folk til at interagere. Opdateringen: "Er ryggen på kjolen ikke fantastisk?" sammen med et billede af Ida Charlotte set bagfra i en af sine fine kjoler ${ }^{4}$ gav ikke færre end 12 kommentarer med alt fra: "Hvor har De fået den lavet?" til: " Det ligner, du har en kæmpe bagdel ; b". Til gengæld gav opdateringen: "Rosenduft, frisk luft, the i haven, latter, solskin, natur - eeeelsker at ligge på landet”, som blev skrevet den 21. juni kun to kommentarer. Det kan selvfølgelig skyldes, at den blev sendt på en dejlig sommerdag, men det kan også skyldes, at en updatering som denne er svær for brugerne at kommentere på. Generelt var der større respons, når der blev formuleret et klart spørgsmål, som folk kunne svare på eller tage stilling til.

Via Facebook kan man få adgang til forskellige funktioner, der kunne hjælpe os med at skabe andre muligheder for interaktion. Applikationen "PollDaddy" gjorde det muligt at lægge afstemninger ud, hvor brugerne både kunne stemme anonymt men også kommentere åbenlyst. Det var med denne funktion, det blev besluttet, at Ida Charlottes lille nye moppe skulle hedde Melampe, og at hun bestemt måtte købe en tobaksdåse til spillelæreren som tak for, at han reddede hende fra den frække, nærgående og yderst upassende ungersvend Ditlev, en ven til Ida Charlottes fætter. Det var også Facebook-vennerne, der hjalp hende med at træffe sit livs beslutning: Skulle hun følge sin fornuft og gifte sig med handelsmanden Jørgen, som var et godt parti, eller skulle hun følge sit hjerte og løbe væk med den ubemidlede spillelærer? Mange deltog i afstemningerne, og en del valgte ligeledes at begrunde deres valg med en kommentar. Og da valget stod mellem kærlighed og fornuft var vennerne på Facebook ikke i tvivl: Ida Charlotte skulle selvfølgelig følge sit hjerte. Det ville nok ikke være sket i 1700-tallet, hvor fornuften rådede. Men vil man lade brugerne være med til at skabe historien, må man også være åben over for deres valg. På trods af udfaldet, lykkedes det alligevel at få diskuteret forskellen mellem fornufts- og kærlighedsægteskab, samt at bevæggrunden for valg af ægtefælle i høj grad er præget af den tid, man lever i og de muligheder, den enkelte person har.

Efter et stykke tid begyndte Ida Charlottes venner selv at spørge om ting, og langsomt 
ændredes dialogen fra primært at være mellem brugerne og Ida Charlotte til, at brugerne også begyndt at kommunikere med hinanden. De mest aktive kendte hinanden og hinandens standpunkter. De vidste hvem, der talte spillelærerens sag og hvem, der stædigt holdt på, at Ida Charlotte selvfølgelig skulle følge sine faders befaling og gifte sig med Jørgen. Men brugerne kunne også hjælpe hinanden og begyndte ofte at svare på hinandens spørgsmål, inden Ida Charlotte overhovedet kunne nå at komme til tasterne. Den 26. maj skrev Ida Charlotte fx på sin side: "Er i dag blevet åreladt - for sundhedens skyld altså. Det er nu smart, altså åreladning - man åbner en blodåre, så kroppen renses. Jeg er desværre så hysterisk inden, selvom det egentlig ikke gør så ondt. Men jeg kan ikke gøre for det - kender i det?" Til denne statusupdatering kom 7 meget lange kommentarer, heriblandt: "Der er nu ikke noget som en halvårlig åreladning.", men også én der stillede spørgsmålet: "Anvender man kopsætning hertil for at trække blodet frem?" Før spørgsmålet blev besvaret, var der en anden, der spurgte: "Hvad er en kopsætning?", og det blev en tredje person som besvarede spørgsmålet med en længere udredning om, hvad en kopsætning bestod i. Brugerne begyndte også at komme med gode ideer, forslag og links til hinanden om materiale til videre læsning, musik fra tiden samt om andre museumsudstillinger eller events om 1700-tallet. Undervejs i projektet opstod der også en slags interessegrupper, og det var muligt at følge, hvilke personer, der interesserede sig for hvad. Fx var der flere mænd, der deltog og kommenterede, da opdateringerne handlede om henrettelsen af Struensee. De var til gengæld ikke rigtigt på banen, da Ida Charlotte bad sine venner om hjælp til, hvad hendes lille hund skulle hedde, eller da hunden løb væk. Her var det i stedet de helt unge piger, som kom på banen.

Da Ida Charlotte skrev sin allersidste updatering på Facebook, var hendes fans ikke klar til at give slip. De fortsatte deres indbyrdes dialog og begyndte sågar at digte videre på historien, så da siden endelig blev lukket ned i midten af november, var der ikke alene skabt interesse for 1700-tallet hos brugerne. Med Ida Charlotte var der også langsomt vokset et fællesskab frem hos en gruppe mennesker med samme interesse for historie og 1700-tal - en interesse der førte til, at brugerne, efter at Ida Charlotte-siden helt blev lukket ned, åbnede deres egen side på Facebook under titlen "Theklubben fra 1772".

\section{Mellem den analoge og digitale Verden}

Som et forsøg skulle det afprøves, om det ville fungere at flytte Ida Charlotte fra den virtuelle verden til den virkelige, og se om det ville forstyrre eller styrke historien at se hende i levende live? Projektet var godt nok ikke skabt med henblik på at lokke flere til fysisk at gå på museum. Det var heller ikke tænkt som en skjult reklame for udvalgte udstillinger, men skabt til nettet og skulle fungere på nettet. Omvendt ville det være sjovt at se, om den megen dialog omkring 1700-tallet skærpede brugernes nysgerrighed for at se eller prøve ting, som har med 1700-tallet at gøre - og for at møde hinanden i virkeligheden. Den digitale formidling skulle gøres analog. Fokusgruppen havde tilkendegivet, at de godt selv kunne finde på at deltage i særlige arrangementer på Nationalmuseet, som $\mathrm{fx}_{\mathrm{x}}$ at prøve tøj eller dans, og de understregede, at de ville deltage eller prøve noget og at det ikke bare skulle være foredrag. I slutningen af september blev der afholdt en afskedsfest hvor Ida Charlottes 


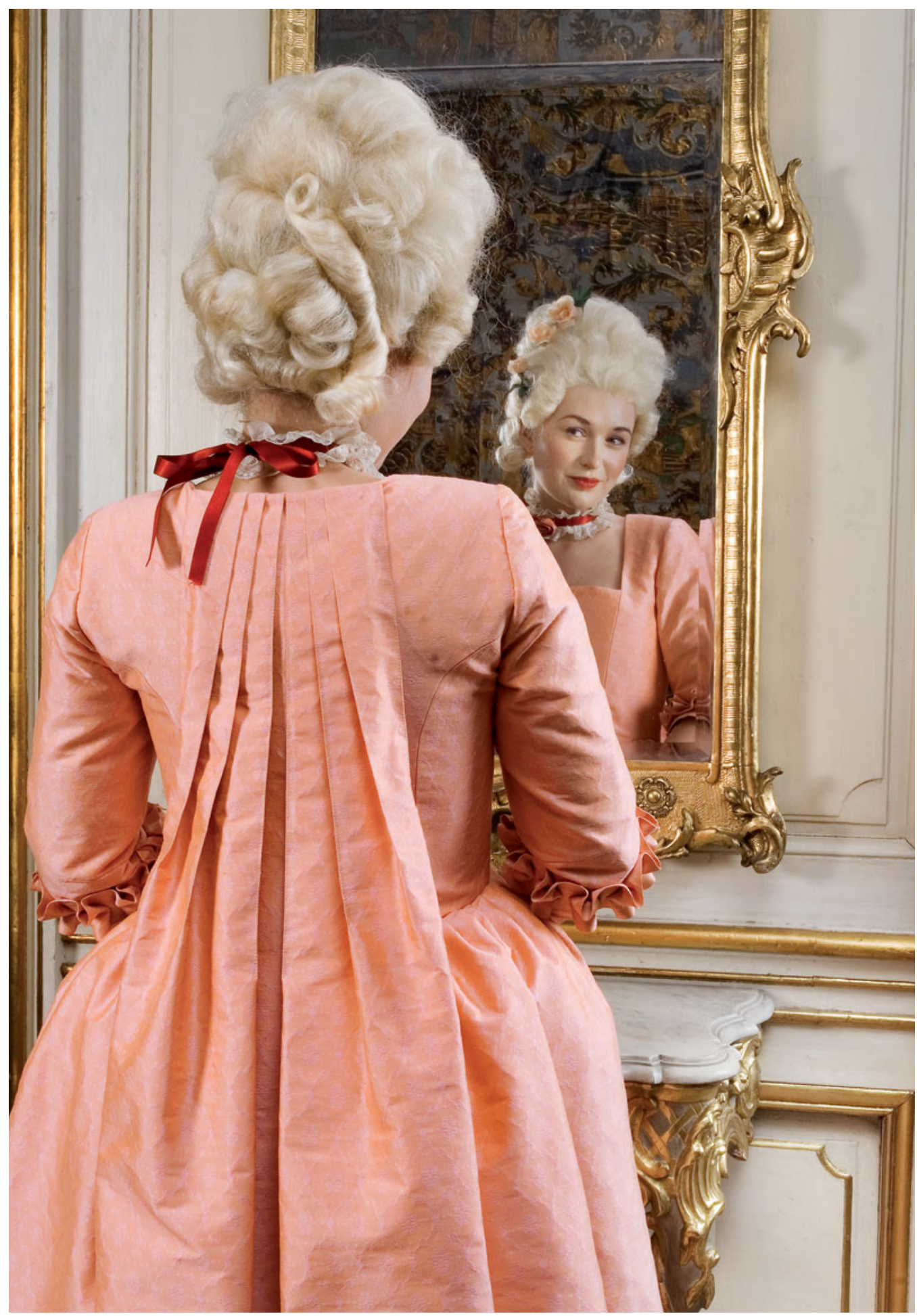

Ida Charlotte ved spejlet i interiørerne i Prinsens Pala, Nationalmuseet. Foto: Nationalmuseet. 


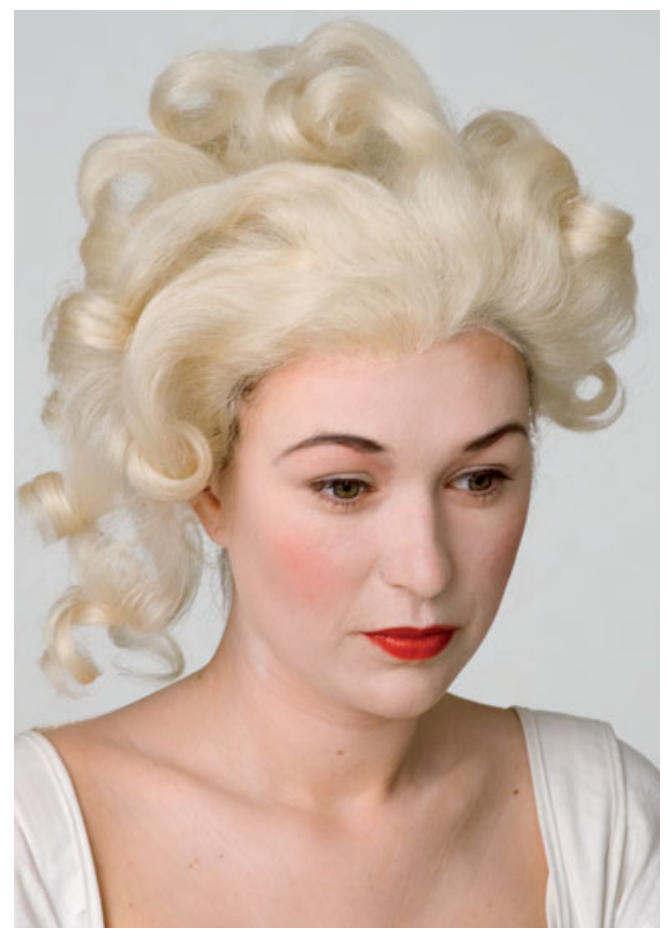

Fig. 2: Under "skabelsen" af Ida Charlotte. Ligesom i 1700-tallet tog det flere timer inden sminken var lagt og håret sat. Foto: Nationalmuseet.

fans kunne danse 1700-tals dans, smage mad lavet som i 1700-tallet, høre opera fra tiden og møde den unge pige. Ballet var det sidste i en række af gratis arrangementer på Nationalmuseet, formidlet gennem Ida Charlotte-siden. Brugerne havde således også haft mulighed for i løbet af det halve år forinden at komme ind og lære at sminke sig og danse, som man gjorde i 1700-tallet samt prøve et par kopier af kjoler og korsetter fra tiden. Vi oplevede, hvordan særligt de unge fans var begejstrede for den fysiske formidling, selvom tilslutningen ikke var overvældende i forhold til Ida Charlottes samlede antal fans. Mange var til- syneladende glade for blot at forblive i den virtuelle faktionsleg, ligesom nogle var forhindret $\mathrm{i}$ at komme til disse fysiske arrangementer, fordi de boede for langt væk - en problematik den virtuelle formidling ikke mødte. Men de, der mødte op var yderst begejstrede og nød at prøve kjoler, sminke sig, og ikke mindst "lege" at de den 25. september 2010 var til 1700-tals bal. Nogle så meget at de ikke på et eneste tidspunkt trådte ud af deres "roller" som 1700-tals mennesker. Med andre ord vakte det begejstring også at kunne få lov at bruge andre sanser end dem man tog i brug $\mathrm{i}$ det virtuelle. Ligeledes oplevede vi også at arrangementerne, og særligt det sidste (ballet), netop af brugerne blev set som en mulighed for at møde hinanden.

\section{NÅEDE PROJEKTET SIN MÅLGRUPPE?}

Da Ida Charlotte skrev sin sidste opdatering 1. oktober var der 854 brugere på hendes side. Ikke umiddelbart noget stort tal. Projektets styrke skal da nok heller ikke findes i antallet af brugere, men snarere i hvem brugerne var, og hvordan de interagerede. I projektets næstsidste uge, dvs. før afstemningen om den unge piges skæbne, havde siden 1.226 besøg og 633 månedlige brugere. Til sammenligning havde Nationalmuseets primære Facebook-side 875 besøg og 402 månedlige brugere - uagtet at fangruppen her omfattede næsten 2.400 personer på det angivne tidspunkt. Opslagskvaliteten på Ida Charlotte-siden var således betydeligt højere end på museets sædvanlige Facebook-side. Med opslagskvaliteten har man mulighed for at måle hvilken respons, der kommer på siden og dermed få et indblik i hvor meget, brugerne engagerer sig og hvordan, man fanger deres interesse. Med Ida Charlotte deltog ca. 800 mennesker gennem 


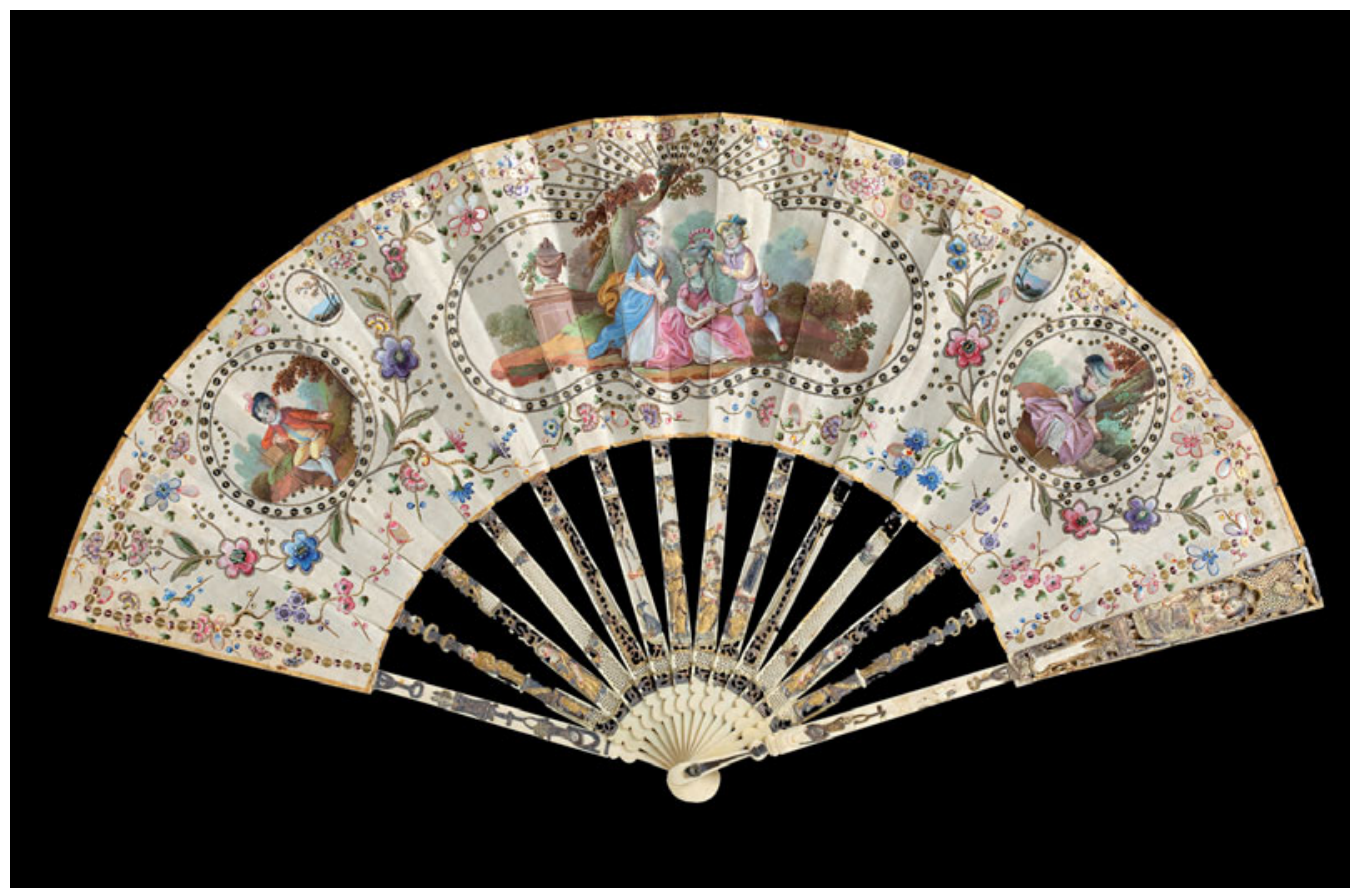

Fig. 3: Fotos af originale genstande fra Nationalmuseets samlinger blev flittigt brugt til at underbygge Ida Charlottes historie. Foto: Nationalmuseet.

mange måneder i en kulturhistorisk aktivitet for nogles vedkommende flere gange om ugen - for andre faktisk dagligt. I modsætning til museernes udstillinger hvor der typisk kommer langt flere mennesker, og hvor besøget jo også varer langt kortere tid. Det vidner om en helt anden form for deltagelse end ved fx museumsbesøg men også om, at forskellige medier kan bidrage til at museerne opbygger meget forskellige relationer til brugerne.

Vil man analysere, hvad der ellers kom ud af projektet, er Facebook et meget taknemmeligt medie at arbejde med. Sidens administratorer kan nøje følge med i brugernes gøren og laden på siden via Facebooks egen statistik. Hver uge kommer der fx opsummeringer om antallet af kommentarer, antallet af brugere som "synes om" samt hvor mange, der har været inde på siden i løbet af den forgangne uge, ligesom man kan se køns- og aldersfordelingen på dem, der har "tilmeldt" sig siden. Statistikken giver imidlertid ikke et indblik i, hvorfor folk har valgt at bruge siden og hvad, de har fàet ud af at følge Ida Charlottes gøren og laden. Da Ida Charlotte havde lavet sin sidste opdatering, blev der lagt et elektronisk spørgeskema på siden, som brugerne kunne besvare. ${ }^{5}$ Ud af de 854 brugere valgte 211 , altså ca. en fjerdedel, at besvare de 10 spørgsmål, og mange skrev desuden egne kommentarer i spørgeskemaet. Med stor sandsynlighed har det nok været de mest interesserede og positi- 
Mette Boritz, Mia Ramsing Jensen, Charlotte S.H. Jensen og Ida Lund-Andersen

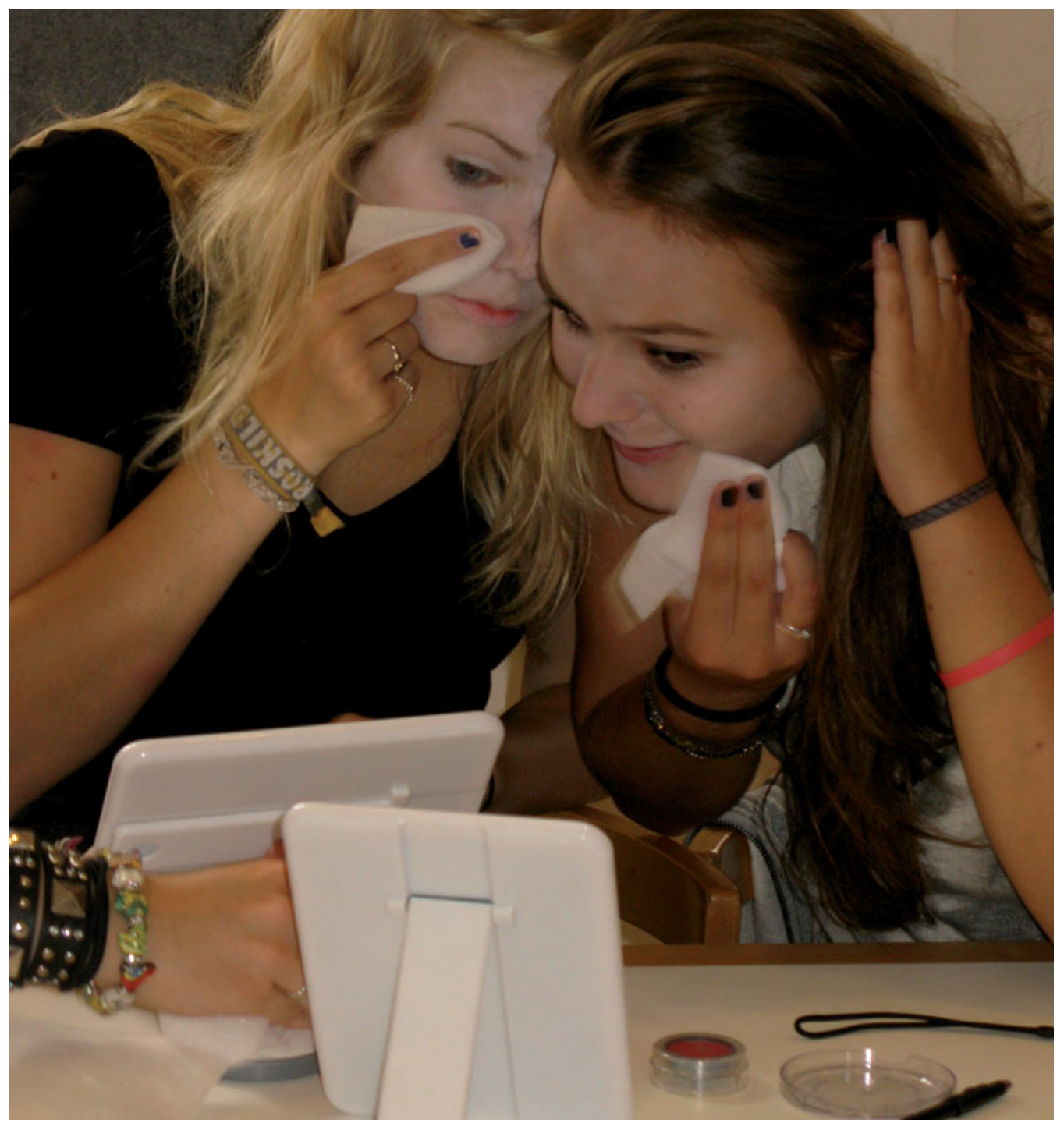

Fig. 4: Unge piger i gang med at sminke sig som Ida Charlotte, ved et af arrangementerne i forbindelse med projektet. Foto: Nationalmuseet.

ve, der ofrede tid på at besvare et spørgeskema. Alligevel giver besvarelserne et billede af projektets udfald. Ud over de 211 besvarelser blev der desuden lavet 5 kvalitative interviews via telefon - både med nogle af de brugere, som havde deltaget meget aktivt på siden, og 
med et par af dem, som nok havde fulgt projektet, men som ikke selv havde deltaget aktivt. Samlet giver alle disse data et godt indblik i ikke bare hvem, der havde valgt at følge projektet men også i hvad, de fx havde făet ud af at deltage.

Ifølge Facebooks registrering var $46 \%$ af de kvinder som havde tilmeldt sig Ida Charlottes side i aldersgruppen 13-34 år, skarpt efterfulgt af den lidt ældre aldersgruppe fra 35 til 54 år, som udgjorde $18 \%$. I spørgeskemaundersøgelsen blev der desuden spurgt til, om Ida Charlottes Facebook-venner i forvejen så sig selv som brugere af Nationalmuseet eller ej. Svarene viste, at $31 \%$ af Facebook-vennerne ofte kom på Nationalmuseet i forvejen, men nok så væsentligt at hele $41 \%$ af Facebookvennerne ikke opfattede sig selv som brugere af Nationalmuseet (nogle af dem havde dog været der engang med skolen). De $41 \%$ havde måske næppe opdaget og deltaget i et projekt som Ida Charlotte, hvis det fysisk havde været placeret på Nationalmuseet. Det vidner om, at de sociale medier, herunder Facebook, godt kan fungere som et sted, hvor museerne kan komme i dialog med brugere - og måske særligt nogle af de unge brugere, som normalt ikke benytter sig af museernes tilbud. Det fortæller samtidig, at det også kan være en vej til at give de faste brugere af museet nye og andre oplevelser med museet end dem, de normalt benytter sig af.

Af dem der havde besvaret spørgeskemaet var $43 \%$ blevet opmærksomme på projektet om Ida Charlotte via en Facebook-ven, 28 \% havde fået kendskab til projektet via Nationalmuseet $^{6}$ og $20 \%$ har anført "andet", hvilket bl.a. kan have været omtale i radioens P1 eller snak med venner og bekendte. Det var således især det sociale netværks egen mekanisme, som skabte kredsen af interesserede ud fra alle- rede deltagendes eksisterende relationer og venskabsforhold. Direkte eller indirekte anbefaling fra venner kan virke meget stærkt, og som et vigtigt incitament til deltagelse. Men det er væsentligt også at være opmærksom på at en brugerskare, der opstår på denne måde, kan have mange træk til fælles, fordi vore venner ikke sjældent ligner os selv. Kun $5 \%$ havde fået kendskab til Ida Charlotte-projektet via de markedsføringsinitiativer, som Nationalmuseet selv havde iværksat i form af annoncer og et gratis postkort, som stod fremme på S-togsstationerne - en markedsføring der, i denne henseende, ikke synes at have den store effekt. Hvad der til gengæld gav en vis effekt i form af nye brugere i den ønskede målgruppe var, da ungdomsbladet "Vi unge" i maj måned bragte en omtale af Ida Charlotte og hendes Facebook-side på deres hjemmeside. Overskriften på omtalen lød: "Hvordan scorede man for 300 år siden”, og de unge kunne bl.a. læse, at den unge Ida Charlotte gik uden underbukser, fik sat sit hår med dyrefedt og $\mathrm{i}$ øvrigt tændte på mænd med pæne ben. I forbindelse med omtalen var der mulighed for, at de unge kunne skrive kommentarer på websiden. Nogle reagerede positivt på opslaget og Ida Charlotte-projektet og syntes, at det var en sjov idé. Andre reagerede mest på oplysningerne i omtalen, hvilket affødte en diskussion blandt de unge om, hvad man så gjorde når man havde menstruation. Og så var der også de kommentarer, der vidnede om, at nogle af de helt unge syntes, at ideen var lidt for "wierdo", "nederen" eller "keeeedeliiiiiiiiiig". 7 Måske var det bare for mærkeligt for nogle af de helt unge brugere, og måske bruger de Facebook og andre sociale medier på en anden måde og til andre formål. Fx indikerer Charlotte Malene Larsens ph.d.-afhandling "Unge og online sociale netværk" fra 2010 
bl.a. en høj grad af sammenhæng mellem de meget unges fysiske venner og mellem det liv, der leves i den virkelige verden og online. Kommentarer m.m. kan være meget korte, og mange skriver med et meget inderligt ordvalg om deres indbyrdes forhold - fx til bedsteveninde og andre meget nære venner. At oprette fangrupper for hinanden, anføre sig som "gift", "forlovet med" eller "søskende til" særlige veninder er ligeledes forekommende. Alt sammen måder at anvende en social platform på, som kun vanskeligt kunne være blevet en del af Ida Charlotte-projektet.

Det blev meget tydeligt undervejs i projektet, hvor meget brugernes interaktion med siden og brug af siden varierede. En almindelig tommelfingerregel for online-communities er 90-9-1 reglen. Dvs. at $90 \%$ af brugerne er "læsere", der kigger med, 9 \% deltager og kommenterer en gang imellem og den sidste 1 $\%$ er superbrugere, som står for hovedparten af kommentarerne og ofte har en høj tilstedeværelsestid, der gør det muligt for dem at reagere meget hurtigt på hændelser i fællesskabet. En tommelfingerregel, som meget godt lod sig afspejle blandt brugerne af Ida Charlottes side. Væsentligt for udviklingen af en digital aktivitetsprofil er derfor også en forståelse for den måde, som brugere ønsker at anvende digitale medier på. Som ved andre aktiviteter, $\mathrm{fx}$ et foredragsarrangement eller lignende, er det langt fra alle, der ønsker at dele deres erfaringer eller stille spørgsmål til oplægsholderen. I communities er det heller ikke ualmindeligt, at en stor del af det aktive engagement bæres af enkelte deltagere. Det var da også langt fra alle Ida Charlottes venner, der kommenterede og skrev med på hendes historie. ”Jeg har vist aldrig selv kommenteret, men det betyder ikke, at jeg ikke har fulgt med", skrev en af brugerne i spørgeskemaet. En 34-årig kvinde,

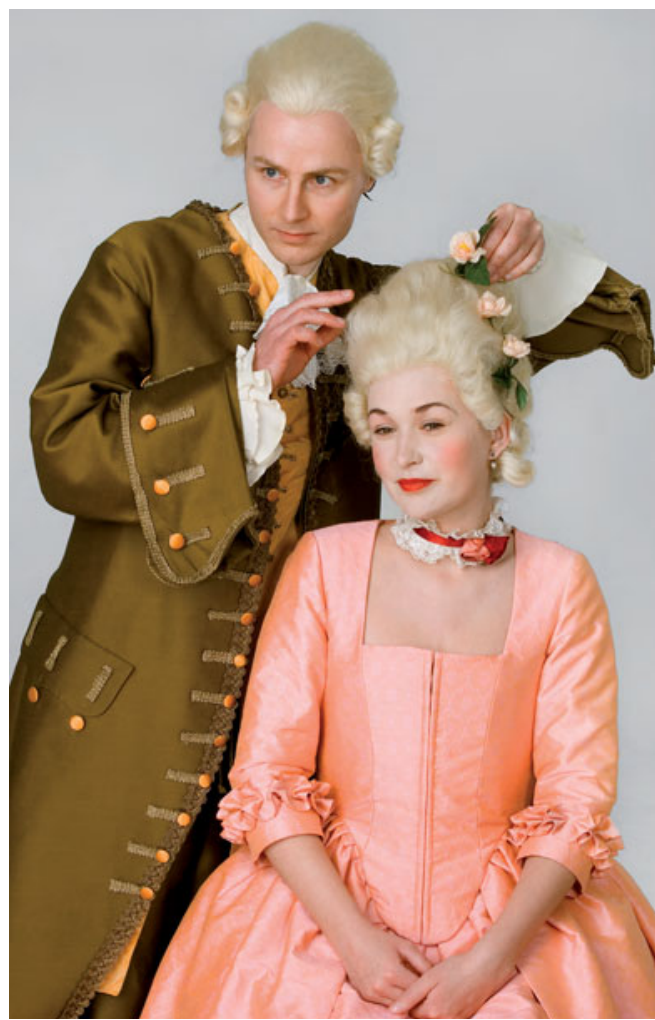

Fig. 5: Ida Charlotte med sin frisør Leonard. Foto: Nationalmuseet.

som efterfølgende blev interviewet om projektet, havde heller ikke selv deltaget aktivt. Hun sagde, at hun ikke helt følte, at hun havde noget at skrive, og når hun læste de andres kommentarer, følte hun, at de var mere inde i sagerne, end hun selv var. De meget aktive brugere kan med andre ord godt have afskrækket nogle fra at skrive, ikke mindst fordi nogle af dem levede sig så meget ind i det, at de endda skrev med et tillempet 1700-tals sprog og stavemåde. Omvendt peger Nina Simon også på, at det netop ikke er alle, som har lyst til at del- 
tage, og at det derfor er vigtigt at skabe mulighed for fleksibilitet, idet man ikke kan regne med, at alle deltager på den samme måde og med samme niveau (Simon 2010). I den henseende fungerede Facebook som medie godt i forbindelse med at tilgodese forskellige digitale livsstile. ${ }^{8}$ Samtidig formåede projektet at få skabt rum, både til dem som havde lyst til meget aktivt at lege med, og til dem, som helst blot ville læse med.

\section{HVAD KAN DEN DIGITALE LEVENDEGøRELSE?}

Med projektet om Ida Charlotte er det lykkedes at engagere og komme i dialog med en målgruppe og nogle mennesker, der ikke normalt eller kun sjældent kommer på museet. Det kan være svært at komme med en entydig forklaring på hvorfor dette lykkedes, og det afsluttende spørgeskema samt de efterfølgende interviews peger da også på, at projektet har ramt flere af brugernes meget forskellige behov og ønsker. Det at flytte formidlingen fra det fysiske rum til den virtuelle verden gav i sig selv nogle geografiske men også nogle tidsmæssige fordele. En af de omtalte interviewpersoner udtrykte netop begejstring for at hun, fordi projektet foregik på Facebook, ikke skulle tage hensyn til åbningstider, og at hun kunne gå til og fra, når det passede hende: "Når barnet er lagt i seng, kan jeg gå på museum." Ligeledes lagde selve udformningen af projektet op til at man kunne "deltage passivt" - man kunne følge med uden direkte at interagere. Hele $35 \%$ af dem der deltog i spørgeskemaundersøgelsen svarede, at det de bedst kunne lide ved projektet var at læse, hvad andre havde skrevet, eller at det bare var sjovt og hyggeligt at være med. Denne besvarelse sender et signal til museumsverdenen om, at det sociale element i læring for mange er af stor betydning. Undersøgelser af bl.a. skolebørns præferencer omkring museumsbesøg viser også, at for at et museumsbesøg skal være vellykket, skal det også være en god social begivenhed, hvor man kan lære med og af sine venner (Groundwater-Smith \& Kelly 2003). Det handler ikke blot om at lære af autoriteterne, men også om at lære med og af andre ligesindede. Det interessante er, at denne mere sociale side af museumsoplevelsen og den læring, som finder sted, også kan skabes i den virtuelle verden, hvilket projektet om Ida Charlotte har været et godt eksempel på. Det peger også på, at museerne med fordel kan bruge medier som Facebook til at facilitere viden samt til at bringe vidt forskellige folk sammen om et emne.

$4 \%$ af de adspurgte svarede, at det, at lære noget om 1700-tallet, havde været det bedste ved at deltage, mens $6 \%$ bedst kunne lide at følge med i Ida Charlottes kærlighedshistorie. Begge svar peger i det små på, at der jo selvfølgelig kan være mange forskellige årsager til at deltage. Nogle søger måske en øget indsigt i en periode, mens andre gerne vil have en "god historie". Særligt interessant i relation til projektets formål var desuden at hele 30 \% svarede at det bedste ved projektet var at leve sig ind i 1700-tallet. Sidstnævnte vidner netop om at levendegørelsen i den grad var til stede hos brugerne til trods for at den var digital og ikke fysisk. Det vidner også om, at den digitale levendegørelse også kan noget i forhold til at få unge (og andre) til et interessere sig for og engagere sig i fortiden. At flytte levendegørelsen fra den analoge til den digitale verden gør samtidig at museet har langt bedre muligheder til rådighed, når man ikke er hæmmet af fysiske eller materielle begrænsninger. Man skal ikke tage hensyn til, at en aktør ikke kan klare sig uden briller, at man ikke må tænde 
ild osv. Med den digitale levendegørelse kan man let og ubesværet bevæge sig fra baggård til de bonede gulve og fra det pulserende byliv til skønne landlige omgivelser. Men når man anvender digital levendegørelse, står man samtidig over for en stor udfordring. Netop fordi oplevelsen ikke er sanselig eller taktil, som den er, når man fysisk befinder sig på et museum, bliver "den gode historie" afgørende for deltagelse og interesse. Tal og kommentarer vidner dog om, at projektet kunne imødekomme både sociale, emotionelle og kognitive behov hos brugerne. Da projektet om Ida Charlotte sluttede, skrev en af de helt unge brugere: "Jeg synes, at det er et rigtig godt projekt i har haft kørende, og selvom jeg kun er 13 år, synes jeg, at det har fanget mig rigtig godt!". En anden skrev: "Det gode var også at det blev bragt ned på dagligdagen. Det var ikke kedelige montrer med lange tekster - det blev bragt ned på hverdagsplan og blev gjort håndgribeligt".

Flere brugere kommenterede at det, at lære noget på en underholdende måde, var en vigtig bevæggrund for at deltage i projektet. Nogle ville endda gerne have haft flere fakta og mere baggrundsmateriale. Som én skrev i spørgeskemaundersøgelsen: "Først vil jeg sige: Hvor var det fantastisk, at I brød muren mellem faglig historieformidling og Facebook ned med så god en historie! Jeg synes, at det er et rigtig godt eksempel på formidling, der tør overskride grænsen mellem fiktion og faglig historieformidling og dermed at gøre historien levende, vel og mærke på hendes egne præmisser". En anden skrev: "Jeg synes at det har været rigtigt underholdende og lærerigt tiltag, det har givet en ny vinkel på historieformidling" og en: "Det er en moderne historieformidling, som åbner for mange andre muligheder. Jeg kan kalde måden Den Oplevende Historieformidling - og den gik rent ind hos mig."
I undersøgelserne blev der imidlertid også plads til lidt konstruktiv kritik. Nogle klagede over, at Ida Charlotte havde været for flittig på tasterne og kom med for mange opdateringer om dagen. En af de interviewede personer kunne godt have tænkt sig, at der var mere sex, drama, kærlighed og snusk fx kysserier ved ballerne osv. Det ville ikke have gjort noget for hendes fornemmelse af den historiske korrekthed. En anden skrev: "Man kan godt blive lidt irriteret på den tåbelige småborgerlige pigeskikkelse, tænk bare at livet kunne være så ensidigt og indskrænket i oplysningstiden".

At drive et projekt som Ida Charlotte er dog mere krævende end som så. Spørgsmål og kommentarer "æder" hurtigt hinanden og gør at overvågningen af siden er meget tidskrævende. Åbner man op for at brugerne skal høres og inddrages, skal deres bidrag også tages alvorligt. I dette tilfælde betød det, at siden, i det halve år, den var i brug, skulle tjekkes flere gange dagligt for at kunne kommentere på eller tilgodese brugernes ønsker. Beslutningen, om at projektet skulle forløbe i realtid, betød samtidig, at det indimellem var nødvendigt at kommentere og lave opdateringer både tidligt om morgenen og sent om aftenen. En anden tidskrævende faktor var, at en sådan faktionsleg stiller krav til en meget bred faglig viden for at kunne holde legen kørende og følge brugernes ønsker og spørgsmål. De aktive brugere og deres mange spørgsmål gav en del researcharbejde, og der skulle handles hurtigt, inden spørgsmålet blev opslugt af nye spørgsmål, kommentarer og opdateringer. Det krævede mange udregninger og opslag en sen aften at finde ud af, hvad et godt stykke linned koster "nu til dags". Ligesom det var vigtigt at sikre, at brugernes kommentarer ikke påvirkede fagligheden i forkert retning. Fx foreslog en bruger en duel for at forsvare Ida Charlottes 
ære. Her måtte der reageres hurtigt, fordi dueller ikke var almindelige i 1772. Samtidig blev der efterhånden skabt en forventning blandt brugerne om, at de også kunne få lov at se fotos af de ting som Ida Charlotte omgav sig med eller skrev om. Da det langt fra er alt fra 1700-tallet, det lige er muligt at finde et passende foto af, måtte der indimellem arbejdes lidt kreativt, og programmer som PhotoShop blev mere end én gang redningen, da Ida Charlottes kjole pludselig skulle være sort, når hun bar sorg - og ikke den vanlige lyserøde. Men en vigtig lære er, at så snart man åbner op for brugerne, skal man også være rede til at tage imod dem. Brugernes konkrete bidrag var jo samtidig afgørende for, at projektet kunne fungere. Selve interaktionen og kommentarerne var samtidig med til at skabe yderligere debat og interaktion. Det forudsatte samtidig, at brugerne havde lyst til at lege med og ikke blot skrev kommentarer som "nederen" eller "nasty" som det skete i "Vi unge"-omtalen kommentarer, det ville være svært at følge op på. Flere kommenterede faktisk i spørgeskemaundersøgelsen, at de var glade for, men samtidig også overraskede over, at ingen undervejs havde forsøgt at ødelægge "legen" med upassende kommentarer eller en useriøs dialog. Projektet kom samtidig til at fungere så godt, fordi der netop var en passende dialog. Mængden af kommentarer gjorde det muligt gennem 6 måneder at opretholde en direkte dialog med alle de aktive brugere. Var antallet af kommentarer eksploderet, ville det ikke have været muligt at interagere på samme niveau, og nogle brugere havde måske følt sig overset. Rigtig mange kommentarer ville måske også virke overvældende at skulle sætte sig ind i og forholde sig til for de brugere, som befandt sig bedst som "passive deltagere".

\section{KONKLUSION}

Generelt kan man sige, at projektet har vakt stor interesse, og mange brugere har, bl.a. på Nationalmuseets almindelige Facebookside, udtrykt ønske om, at Nationalmuseet vil gentage succesen med lignende projekter - f.eks. en anden person fra en anden tidsperiode. Relevant er det selvfølgelig at stille spørgsmålene: Fik vi fat i de unge brugere? Fik vi engageret dem? Og hvilken fremtid peger projektet i retning af - både for Nationalmuseet selv, men også for andre museer?

Som tidligere nævnt havde Ida Charlotte 854 fans, da siden lukkede ned. I det halve år, siden eksisterede, brugte vi 255.000 kroner og var 4 medarbejdere, der brugte omkring 1100 timer. Nogle vil mene, at det er mange penge og mange timer i forhold til de 854 fans og spørgsmålet, om det var det værd, er i denne sammenhæng uundgåeligt. Vi synes, det har været alle pengene og anstrengelserne værd og det af flere årsager. Vi har engageret et relativt stort antal mennesker over en længere periode, modsat den tid en besøgende på et museum er engageret i en bestemt udstilling eller arrangement på museet. Ligeledes har vi også engageret mennesker, der geografisk befandt sig langt væk fra Nationalmuseet. Yderligere viser tallene, at en stor procentdel af sidens tilmeldte netop kom fra målgruppen de 15-30 årige kvinder, og mange af dem, der efterfølgende besvarede det spørgeskema, ikke anså sig selv som brugere af Nationalmuseet. Disse resultater skal selvfølgelig ikke ses som et udtryk for at projektet var ufejlbart eller udelukkende succesfuldt. Vi kunne måske have nået endnu flere fra målgruppen og aktivt engageret dem, hvis vi fx havde markedsført Ida Charlotte anderledes. Men skal vi vurdere hvad resultatet af projektet har været, er den viden om digital 
og interaktiv museumsformidling, vi har fået, næsten uvurderlig. Med fingrene i et konkret projekt er det netop muligt at opleve og erfare hvilke udfordringer samt fordele og ulemper, der ligger $\mathrm{i}$ at søsætte et digitaliseret projekt som Ida Charlotte - lige fra brugerinddragelse til ressourcer. Den digitale levendegørelse har bestemt ulemper i form af ikke at være sanselig eller taktil på samme måde som levendegørelse i den analoge verden. Til gengæld rækker den, i sin digitale form, langt ud over museets grænser og åbningstider og puster nyt liv i mulighederne for at arbejde i realtid, hvor den gode historie kan være med til at fange og engagere brugerne. Den digitale levendegørelse har netop, i sin form af en faktionsleg, gjort det muligt at skabe en identificerbar formidlingsform, hvor unge piger oplevede og skabte historien sammen med en anden ung pige. Den ene del er ren fiktion, mens den anden er som faktuel historie gjort vedkommende. Hvad projektet særligt har vist er, at mange helt tydeligt har noget at sige og bidrage med i forhold til museernes formidling, og at de i den grad kan lære noget af hinanden. Dette peger igen i retning af hvor vigtigt, det er, at museerne tilskynder denne proces ved at fungere som facilitator og samtidig autoritet. Mange undersøgelser viser, at det, at gå på museum, ofte er en social begivenhed. Med Facebook som platform har det vist sig, at det sociale absolut ikke behøver at falde bort, blot fordi man ikke fysisk er sammen. Tværtimod tyder Ida Charlotte projektet på, at behovet for at være social og for at opleve samme sagtens kan imødekommes i det virtuelle. Endda tyder meget på, at det sociale aspekt blev udvidet yderligere, eftersom brugerne gerne ville både interagere med "fremmede", lære dem at kende og høre, hvad de havde at sige. Til trods for projektets mange spændende resultater, skal de dog ikke forstås som udtryk for en holdning, der advokerer, at digital levendegørelse og formidling helt skal eller overhovedet kan erstatte den mere traditionelle museumsformidling eller udstillinger. De skal dog ses som et interessant indblik $\mathrm{i}$, hvad fremtiden bringer af spændende supplementer og videreudvikling af den velkendte museumsformidling.

\section{NOTER}

1. Ifølge Facebooks egen annoncegenerator vil man, hvis man laver en målrettet annonce den 24 . januar 2011, kunne nå 754.020 personer, der ifølge de oprettede statusprofiler, opfylder følgende 3 kriterier: De bor i Danmark, de er præcis 35 år eller yngre, og de er kvinder.

2. Definitionerne er her hentet fra International Museum Theatre Alliance's (IMTA) hjemmeside http://www.imtal-europe.com/resources.php

3. Anette Hoff: Karen Rosenkrantz de Lichtenbergs dagboger og regnskaber. Hverdagsliv 1771-1796 på herregården Bidstrup og i Horsens. Horsens $\mathrm{Mu}-$ seum og Lanbohistorisk Selskab 2009.Karen køber tre år i træk (1792 - 1794) 58 pund $(29 \mathrm{~kg})$ pudder. NB: I København er det på det tidspunkt gået af mode med så meget pudder, men Karen bor jo langt fra Staden og er blevet ældre. To andre vigtige dagbogskrivere var søofficeren Peter Schiønning og apoteketerfruen Anne Sofie Becker.

4. Updated den 5. juli 2010.

5. Spørgeskemaet blev lavet med PollDaddy applikationen.

6. $14 \%$ af dem som besvarede spørgeskemaet var enten selv tilknyttet Nationalmuseet eller havde venner eller familie på museet; $9 \%$ så det via $\mathrm{Na}$ tionalmuseets Facebook- side og 5\% fra Nationalmuseets website. 
7. http://www.viunge.dk/Teenager/Guides_Tips/ Hvordan_scorede_unge_for_300_aar_siden.aspx

8. En undersøgelse af digitale livsstile, som tns Gallup publicerede i efteråret 2010, viste bl.a, at internetpenetrationen i Danmark ligger på $86,10 \%$. Dette angiver den procentdel af den danske befolkning, som har adgang til internettet. Undersøgelsen viste også, at hovedparten af danskere kan karakteriseres som funktionelle (32\%), der primært anvender nettet til at finde faktuelle oplysninger o.lign. eller netværkere (22\%) der anvender digitale medier til sociale aktiviteter. En anden gruppe udgøres af "Influencers", der som regel er yngre og storforbrugere af digitale ytringsmuligheder.

\section{Referencer}

Anderson, J (1986): Time Machines - The World of Living History. The American Association for State and Local History. Nashville, Tennessee.

Anderson, J (Ed) (1991): A Living History ReaderVolume 1. Museums. The American Association for State and Local History, Nashville, Tennessee.

Black, G (2005): The Engaging Museum - Developing Museums for Visitor Involvement. Routledge, London.

Boritz, M (2000): "Anne Christine Beckers dagbog 1887-1790. Ideal og praksis i borgerskabskvindernes liv". I Fortid og nutid $2000 \mathrm{nr} .4 \mathrm{pp}$ 251-270.

Carstensen, J, Meiners, U \& Mohrmann, R (Eds) (2008): Living History im Museum - Möglichkeiten und Grenzen einer populären Vermittlungsform. Waxmann, Berlin.

Falk, J \& Dierking, L ( 1992): The Museum Experience Whalesback Books, Whasington DC.

Floris, L \& Vasström, A (1999): På museum. Roskilde Universitets Forlag.

Gibbs, Kirsten; Sani, Margherita; Thompson, Jane (eds) (2007) Lifelong Learning in Museums - A

European Handbook. Ferrara 2007.

Groundwater-Smith, S \& Kelly, L (2003): As We See

It: Improving Learning in the Museum, paper represented to the British Educational Research Annual Conference, Edinburgh, september 2003.

Gurian, E (2007): "The Potential of Museum Learning - The Essential Museum”. In: Lord, B (ed): The Manual of Museum Learning. AltaMira Press, Plymouth.

Hansen, H (2003): "Om en levendegjort fortid". Museumsformidlere i Danmark, MID, Nyhedsbrev nr. 8. februar 2003 pp 11-13.

Hoff, A (2009): Karen Rosenkrantz de Lichtenbergs dagboger og regnskaber. Hverdagsliv 1771-1796 på herregården Bidstrup og i Horsens. Horsens $\mathrm{Mu}-$ seum og Landbohistorisk Selskab 2009.

Hunt, Stephen (2004): “Acting the part:"living history" as a serious leisure pursuit". In: Leisure Studies Vol 23, No 4, October 2004 pp 387-403.

Jørgensen, A (2003): “Levendegørelse”. In Museumsformidlere i Danmark, MID, Nyhedsbrev nr. 8. februar 2003 pp 4-5.

KUAS (2009): National brugerundersøgelse på de statslige og statsanerkendte museer i Danmark. Kulturarvsstyrelsen 2009.

Larsen, C (2010): Unge og online sociale netverk. Ph.d. afhandling upubliceret.

Message, K (2006): New Museums and the Making of Culture. Berg, Oxford.

Nielsen, J: (2006) Participation Inequality: Encouraging More users to Contribute www.usite.com

Simon, N (2010): The Participatory Museum. Museumz, California.

Stoklund, B (1993): "International Exhibitions and the New Museum Concepts in the latter Half of the Nineteenth Century". In Ethnologia Scandinavica 23 pp $87-113$.

Stoklund, B (1994): "The Role of the International Exhbitions in the Construction of National Cul- 
tures in the 19th Century". In: Ethnologia Europaea $n r 24 \mathrm{pp} 35-44$.

Ronsheim, R (1991): “Is the past dead?" In: Anderson, J (Ed) (1991): A Living History Reader - Volume 1. Museums. The American Association for State and Local History, Nashville Tennessee

Zakrisson, I (2003): "Stoppa Tiden! Levendegørelse på Hallwylska Museet". In: Museumsformidlere $i$ Danmark, MID, Nyhedsbrev nr. 8. februar 2003 pp 11-13.

Aakjær, M (2008): "Levendegørelse - en anden måde at lave god formidling på?”. In: NORDNYTT nr. $105 / 2008$ pp $27-37$.

*Mette Boritz, ph.d-stipendiat/museumsinspektør Nationalmuseet.

Adresse: Nationalmuseet, Forsknings- og Formidlingsafdelingen, CFF. Frederiksholms Kanal 12, 1220 København $K$

E-mail:mette.boritz@natmus.dk

* Mia Ramsing Jensen, stud mag. Europaisk Etnologi, Københavns Universitet samt studentermedhjelp Nationalmuseet.

Adresse: Nationalmuseet, Frederiksholms Kanal 12, 1220 København $K$

E-mail: miaramsing@natmus.dk
*Charlotte S.H. Jensen, mag. art. Webredaktør Nationalmuseet, Forsknings- og Formidlingsafdelingen, CSA.

Adresse: Nationalmuseet, Frederiksholms Kanal 12, 1220 København $K$

E-mail: Charlotte.S.H.Jensen@natmus.dk

*Ida Lund-Andersen, cand.mag.

Museumsinspektør, Nationalmuseet, Forsknings- og Formidlingsafdelingen, CFF.

Adresse: Nationalmuseet, Frederiksholms Kanal 12, 1220 København $K$

E-mail:Ida.Lund-Andersen@natmus.dk 